\title{
BACTERIAL FLORA OF MUD CRAB, SCYLLA OLIVACEA, COLLECTED FROM DIFFERENT MARKETS OF DHAKA CITY
}

\author{
Farhana Karim, Md. Ghulam Mustafa*, Dewan Ali Ahsan and \\ Md. Anisur Rahman Khan ${ }^{1}$ \\ Department of Fisheries, University of Dhaka, Dhaka-1000, Bangladesh
}

\begin{abstract}
The present study was carried out to investigate the bacterial flora of mud crab (Scylla olivacea) meat collected from the five markets of Dhaka city. Faecal Coliform, Salmonella sp. and Shigella sp., E. coil, and Vibrio spp. were detected in most of the samples except the frozen ones from Agora super shop. The samples from Basabo and Karwan bazar had higher bacterial load than the others. The highest TBC counts were observed in the samples from Karwan bazar $\left(38.1 \pm 1.20 \times 10^{4} \mathrm{cfu} / \mathrm{g}\right)$ and the lowest were from Agora super shop (4.48 \pm 0.26 $\left.\mathrm{x} 10^{4} \mathrm{cfu} / \mathrm{g}\right)$. The total Vibrio spp. counts were found only in two markets, i.e. from Farmgate and Basabo. The total E. coli counts ranged from $1.25 \pm 0.02 \mathrm{x}$ $10^{4} \mathrm{cfu} / \mathrm{g}$ to $4.33 \pm 0.56 \times 10^{4} \mathrm{cfu} / \mathrm{g}$. The Salmonella and Shigella counts varied between3.95 $\pm 0.28 \times 10^{4} \mathrm{cfu} / \mathrm{g}$ for Karwan bazaar and $16.76 \pm 1.26 \times 10^{4} \mathrm{cfu} / \mathrm{g}$ for Basabo. Total Staphylococcus spp. counts ranged between $14.4 \pm 1.1 \mathrm{x}$ $10^{4} \mathrm{cfu} / \mathrm{g}$ and $20.01 \pm 1.94 \mathrm{x} 10^{4} \mathrm{cfu} / \mathrm{g}$ for normal crab samples and $0.37 \pm 0.025 \mathrm{x}$ $10^{4} \mathrm{cfu} / \mathrm{g}$ for frozen samples. The results of this study showed that the bacterial load was significantly higher in live crab than the frozen crab indicating that later are safe for human consumption.
\end{abstract}

Key words: Mud crab, bacterial flora, local markets, Dhaka city.

\section{INTRODUCTION}

Scylla olivacea is an economically important species found in the estuaries and mangroves of tropical countries. Mud crabs occur abundantly in the coastal region of Bangladesh, especially in the coastal areas of Chakoria, Moheskhali and Kutubdia Island in Cox's Bazar district and Khulna, Satkhira and Bagerhat in the Sundarbans regions (Ahmed 1992). Bangladesh began exporting mud crabs around 1997-98 and since then the value of export earnings has been steadily increasing. In 2002, mud crabs ranked third in terms of frozen food export items. During 2009-10, Bangladesh exported 580 tons crab of USD 3 million (BEPB, 2009-10) to China, Hong Kong, Malaysia, Korea and Taiwan. Especially female crabs are playing an important role in marketing, particularly in Asian countries such as Japan, Taiwan, Hong Kong and Singapore. Also, there is a growing market for mud crab meat as a value added product and for frozen soft-shelled mud crab in the USA.

Fish and shellfish not only transmit disease to man but are themselves subject to many food borne microbial infections and intoxications (Emikpe et al. 2011). One of the major risks involves as the consumption of raw or

\footnotetext{
* Author for correspondence: <mghulam@du.ac.bd>. ${ }^{1}$ Department of Microbiology, University of Dhaka, Dhaka-1000, Bangladesh
} 
undercooked crab that may be naturally contaminated by food borne pathogens present in the environment. Such risk is further increased if the food is mishandled during processing where pathogens could multiply exponentially under favourable conditions.

The environment has a great influence on the bacterial flora of freshly caught crabs. During handling, bacteria present on the body surface or in the intestine can enter the crab meat and cause contamination. Aquatic crustaceans always exercise large number of microbes into their body parts from water, sediments and food. The increase demand of mud crab production and their value for export, attention should be given to their microbiological quality and concerning food safety for human consumption.

The quality of processed products largely depends on the raw materials and method of handling. Along the entire production chain maintenance of hygienic condition and proper handling is very important. The present attempt had been made to assess the bacterial contents of Scylla olivacea collected from local fish markets of Dhaka city.

\section{MATERIAL AND METHODS}

The study was carried out in the laboratory of the Department of Microbiology of the University of Dhaka. The experiment was carried out from September 2013 to March, 2014. Mud crab (Scylla olivacea) was selected for this experiment. Both normal and frozen conditions were considered for study. Crabs were collected from five different locations (Mohakhali, Karwan Bazar, Farmgate, Basabo and Dhanmondi Agora super shop). Live samples were collected from Mohakhali, Karwan Bazar, Farmgate and Basabo market and frozen samples from Dhanmondi Agora super shop. Most of these harvested crabs were transported from Cox's Bazar to Dhaka and the crab collectors collected rest of the crabs from the Sundarban mangrove forest, ghers and rivers/canals. Frozen crabs were brought to the laboratory in ice box. Live samples were collected in sterile polythene bags. Samples were washed several times with distilled water to prevent contamination from shell surface and mantle fluid.

Seven media were used for bacterial isolation [Nutrient Agar (For total aerobic mesophilic plate count), $\mathrm{mFC}$ Agar (Total and fecal coliform that gives blue colonies), MacConkey Agar (Enterobacteriaceae. Lactose fermenters give pink colonies), TCBS Agar (Pathogenic Vibrio spp. gives yellow colony while the non-pathogenic is green), SS Agar (Salmonella spp. gives dark black centered colony and Shigella spp. gives clear colonies), EMB Agar (For E. coli that gives green metallic sheen), Minitol Salt Agar [For Staphylococcus spp (APHA 1998, EEC 1992)].

The samples were homogenized separately in normal saline using homogenizer for bacteriological analysis. Then the samples were serially diluted and made up to $10^{-5}$ dilution. Spread plate technique was used for isolation and 
enumeration of the microorganisms present in the collected samples (APHA 1998. All the plates were transferred to the incubator at $37^{\circ} \mathrm{C}(\mathrm{mFC}$ plates at $44^{\circ} \mathrm{C}$ ) for 24 hours to grow target bacteria. The countable range of bacterial colonies is 30-300 in a plate. The counts were expressed as colony forming unit (cfu) per gram.

Total bacterial count (TBC): All the colonies within the countable range on nutrient agar plate were counted as TBC. Thus, cfu/g for 2 replicates were initially averaged and used for final calculation. Total coliform (TC) For the enumeration of total coliform membrane fecal coliform $(\mathrm{mFC})$ agar plate was used. Plates were incubated at $37^{\circ} \mathrm{C}$ for 18 to 24 hours. Blue colonies were considered as total coliform. Fecal coliform (FC) For the enumeration of fecal coliform same procedure was followed as the enumeration of total coliform except the incubation temperature; $44^{\circ} \mathrm{C}$ for overnight. Vibrio spp. count All the colonies of yellow and green color on TCBS plate after 18-24 h of incubation were counted as Vibrio cfu/g. E. coli count All the colonies of blue black colour with green metallic sheen on EMB plate after 18-24 h of incubation were counted as E. coli cfu/g. Salmonella spp. and Shigella spp. count Colourless and black centered colonies on SS agar were counted as Salmonella spp. and Shigella spp. cfu/g. Staphylococcus spp. count Colonies on MSA plate were considered as Staphylo spp. count.

Different types of colonies in various media were observed. Morphological characteristics including shape, size, edge, elevation, colour etc. were studied. Biochemical tests like; oxidase test, catalase test, KIA test, motility detection, carbohydrate fermentation test, indole test (tryptone broth), citrate test (Simmon's citrate slant), methyl red test(MRVP broth), Voges-Proskauer test, nitrate reduction test, salt tolerance test were performed to identify the isolates.

The means of bacterial load were compared using SEM and ANOVA followed by Tukey's post hoc for multiple comparisons. Statistical software SPSS version 20.0 was used to analyze the data with the level of significance at $\mathrm{p}<0.05$.

\section{RESULTS AND DISCUSSION}

The results of total bacterial counts (TBC), total coliform (TC), fecal coliform (FC) and total Staphylococcus spp. counts of mud crab (Scylla olivacea) meat are shown in Table 1. Samples from Agora super shop were in frozen condition and from other four markets were in normal condition. 
Table 1. The density (cfu/g) of TBC, TC, FC and total Staphylococcus like colonies in mud crab (Scylla olivacea) meat*

\begin{tabular}{lcccc}
\hline Sources & $\begin{array}{c}\text { TBC }\left(10^{4}\right) \\
\mathrm{cfu} / \mathrm{g}\end{array}$ & $\begin{array}{c}\text { TC }\left(10^{4}\right) \\
\mathrm{cfu} / \mathrm{g}\end{array}$ & $\begin{array}{c}\text { FC }\left(10^{4}\right) \\
\mathrm{cfu} / \mathrm{g}\end{array}$ & $\begin{array}{c}\text { Total Staphylococcus } \\
\text { spp. }\left(10^{4}\right) \mathrm{cfu} / \mathrm{g}\end{array}$ \\
\hline Mohakhali & $23.07 \pm 1.24^{\mathrm{b}}$ & $9.85 \pm 0.45^{\mathrm{a}}$ & $3.02 \pm 0.01^{\mathrm{b}}$ & $14.4 \pm 1.1^{\mathrm{a}}$ \\
Karwan Bazar & $38.1 \pm 1.20^{\mathrm{a}}$ & $9.61 \pm 0.71^{\mathrm{a}}$ & $4.47 \pm 0.22^{\mathrm{a}}$ & $16.61 \pm 1.71^{\mathrm{a}}$ \\
Farmgate & $23.83 \pm 0.80^{\mathrm{b}}$ & $8.36 \pm 0.36^{\mathrm{a}}$ & $2.25 \pm 0.25^{\mathrm{b}}$ & $17.88 \pm 0.85^{\mathrm{a}}$ \\
Basabo & $25.93 \pm 0.63^{\mathrm{b}}$ & $10.55 \pm 0.65^{\mathrm{a}}$ & $2.82 \pm 0.14^{\mathrm{b}}$ & $20.01 \pm 1.94^{\mathrm{a}}$ \\
Agora & $4.48 \pm 0.26^{\mathrm{c}}$ & $0.0 \pm 0.0$ & $0.0 \pm 0.0$ & $0.37 \pm 0.025^{\mathrm{b}}$ \\
\hline
\end{tabular}

*Means ( \pm SEM) within row and column for total and column with different letters are significantly different (ANOVA, HSD, $\mathrm{p}<0.05$ ).

TBC counts ranged from $4.48 \pm 0.26 \times 10^{4} \mathrm{cfu} / \mathrm{g}$ to38.1 $\pm 1.20 \times 10^{4} \mathrm{cfu} / \mathrm{g}$ (Table 1). The results of the bacterial analysis of fresh crabs bought from four markets in Dhaka city indicate high levels of contamination with pathogenic bacteria. The highest TBC counts were observed in the samples from Karwan bazar and the lowest were from Agora super market. Total coliform and staphylococcal counts of the crab samples were also above the acceptable limit (coliform $<10^{2} \mathrm{cfu} / \mathrm{g}$, coagulase positive staphylococcus $<10^{2} \mathrm{cfu} / \mathrm{g}$ ) according to Whong et al.(2003). Staphylococci counts of live crabs were not within the acceptable limit $\left(10^{3} \mathrm{cfu} \mathrm{g}^{-1}\right)$ recommended by ICMSF (1998). The results confirmed that the samples of local markets contained high pathogenic bacterial load which are supposed to be a threat to food safety creating food borne diseases (Nilla, et al., 2012).The high total aerobic counts is an indication of reduced shelf-life for the crab meats while the high coliform and staphylococcal counts is an indication of potential food infection/ intoxication (Buchanan, 1991). The TBC counts of this study were more or less similar to the study of Lalitha et al., 2012. The frozen samples from Agora super shop had significant lower level of bacterial counts. Vibrio, E. coli, Total coliform, fecal coliform, Salmonella, Shigella were absent in those samples. This indicates the good quality of the frozen product.

There were no significant differences $(\mathrm{p}>0.05)$ in the counts of the total coliforms $\left(8.36 \pm 0.36^{\mathrm{a}} \times 10^{4} \mathrm{cfu} / \mathrm{g}\right.$ to $\left.10.55 \pm 0.65^{\mathrm{a}} \times 10^{4} \mathrm{cfu} / \mathrm{g}\right)$ of the samples obtained from the five markets. The highest staphylococcal counts were obtained from Basabo market, 20.01 $\pm 1.94^{\mathrm{a}} \times 10^{4} \mathrm{cfu} / \mathrm{g}$ while the least count was obtained from the Agora super shop, $0.37 \pm 0.025^{\mathrm{b}} \times 10^{4} \mathrm{cfu} / \mathrm{g}$ (Table 1). The results of the study indicate that good handling and post-harvest practices should be adopted to improve the microbiological quality of mud crab. While analyzing fresh picked crab meat from twelve different blue crab processing facilities, Reinhard et al. (1996) observed coliform and fecal coliform counts in the range of $<0.3$ to $32.8 \mathrm{MPN} \mathrm{g}^{-1}$ and $<0.3$ to $2.26 \mathrm{MPN}$ g-1, respectively and Escherichia coli counts ranged from $<0.3$ to $0.77 \mathrm{MPN} \mathrm{g}^{-1}$. 
Significant differences exist in the staphylococcal counts of the crabs obtained from the five markets. The high staphylococcal counts in all the crab samples may be due to the fact that crabs are constantly being touched by both buyers and sellers, thus introducing and increasing the population of Staphylococcus aureus. Edema (2008) is of the view that staphylococcal counts exceeding $10^{2}$ cells/g in foods may be associated with gross mishandling and contamination.

The samples of crab analyzed bacteriologically showed presence of Vibrio spp. contamination in two markets only; Farmgate and Basabo; ranged between 10.76 $\pm 0.46 \times 10^{4} \mathrm{cfu} / \mathrm{g}$ and12.54 $\pm 0.38 \times 10^{4} \mathrm{cfu} / \mathrm{g}$ (Fig. 1). International Commission of Microbiological Specification for Foods (ICMSF, 1998) recommended that counts of chilled/frozen crab meat should below $10^{5} \mathrm{cfu} / \mathrm{g}$ and the maximum counts of Vibrio spp. should be $1 \times 10^{2}$. But the result of present study exceeds the level.

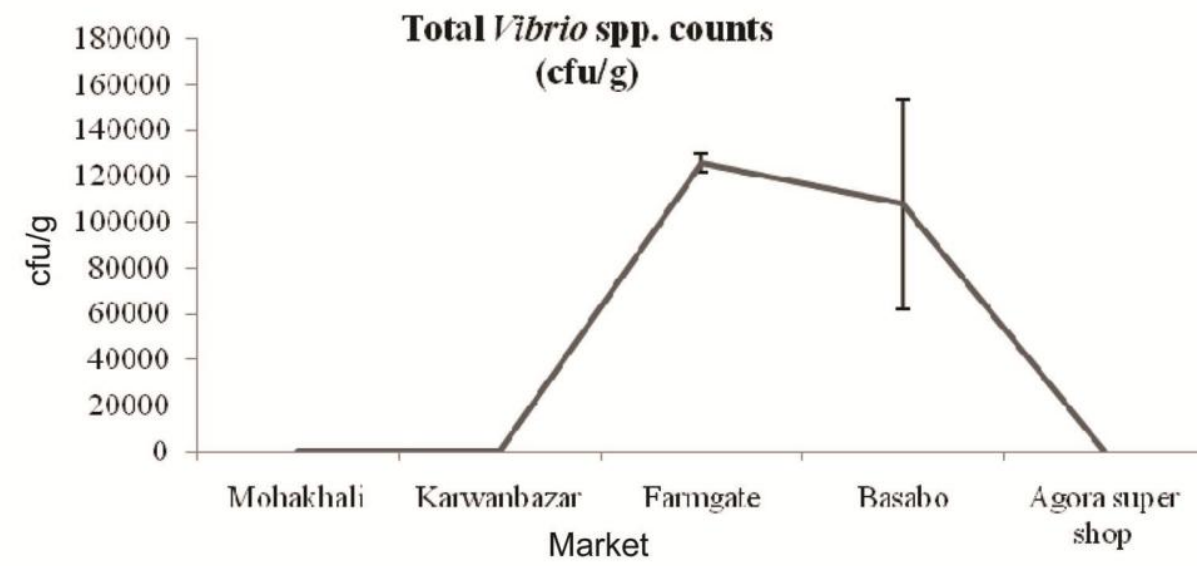

Fig. 1. The local markets of mud crab sample collection plotted against total Vibrio counts (cfu/g)

The counts of the total E. coli were $4.33 \pm 0.56 \times 10^{4} \mathrm{cfu} / \mathrm{g}$ for Karwan bazar, $3.19 \pm 0.21 \times 10^{4} \mathrm{cfu} / \mathrm{g}$ for Mohakhali, $2.33 \pm 0.31 \times 10^{4} \mathrm{cfu} / \mathrm{g}$ for Basabo, 1.25 $\pm 0.02 \times 10^{4} \mathrm{cfu} / \mathrm{g}$ for Farmgate and $0.0 \pm 0.0 \times 10^{4} \mathrm{cfu} / \mathrm{g}$ for Agora super shop (Fig. 2). Escherichia coli were recovered from all the four normal crab samples. The results of the study indicate that good handling and post-harvest practices should be adopted to improve the microbiological quality of mud crab. E. coli counts in fresh crab meat from all four markets were within the maximum limit for acceptability of crab meat, as recommended by the ICMSF (1998). The presence of Escherichia coli in all the samples except the frozen one may be suggestive of fecal contamination due to poor hygiene and sanitation. E. coli has been implicated in human diarrheal particularly type 0157:H7 (Nester et al., 2007). 
Total E. coli counts (cfu/g)

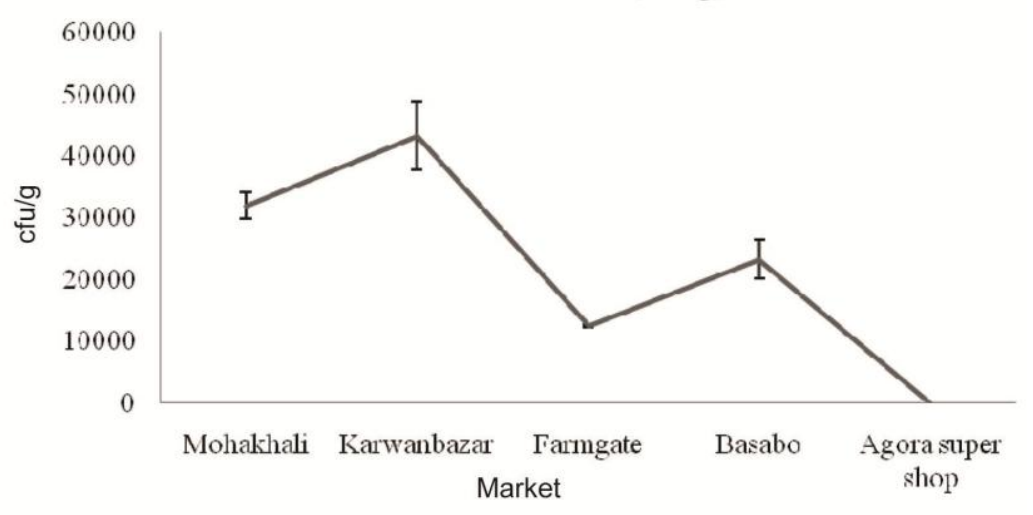

Fig. 2. The local markets of mud crab sample collection plotted against total $E$. coli counts (cfu/g).

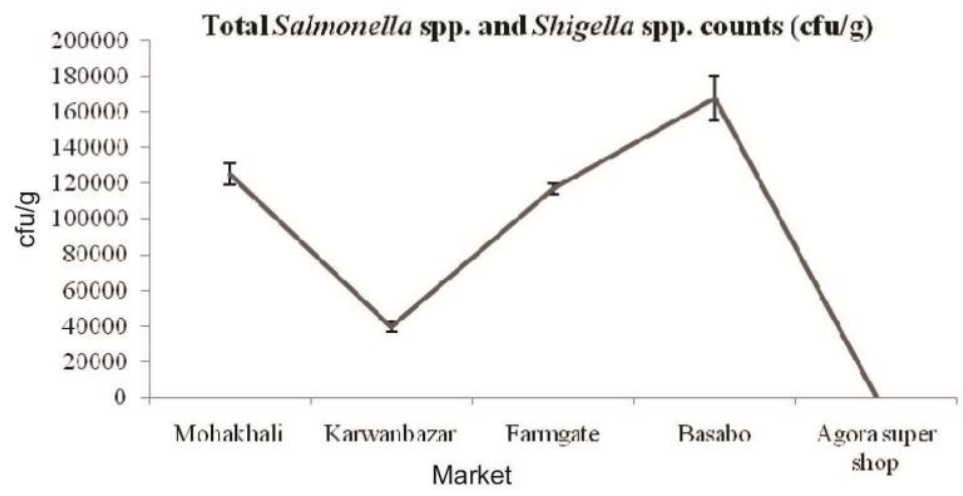

Fig. 3. The local markets of mud crab sample collection plotted against the total Salmonella spp. and Shigella spp. counts (cfu/g).

The Salmonella spp. and Shigella spp. counts were found in all four markets except Agora; ranged from $3.95 \pm 0.28 \times 10^{4} \mathrm{cfu} / \mathrm{g}$ at Karwan bazar to $16.76 \pm$ $1.26 \times 10^{4} \mathrm{cfu} / \mathrm{g}$ at Basabo. The presence of Salmonella spp. and Shigella spp. in the crab samples may be due to exposure to prevailing unhygienic and poor sanitary conditions in the markets. Salmonella and Shigella are well-known important human pathogens. Their presence is unacceptable because of their attendant health risks (Mensah et al. 2002). Significant numbers of detections of Salmonella spp. in fish and fishery products indicate that current strategies for Salmonella control in the aquaculture production and processing sectors are not adequate. While some crabs caught offshore and handled hygienically and at low temperature according to the Codex Code of Practice for fish and fishery products (CAC/RCP/52-2003) may be suitable for raw consumption, it would be advisable to consume products of aquaculture only after cooking (Reinhard et al, 
1999). The Salmonella problem should be resolved by the use of good manufacturing procedures and the strict application of sanitary practices. On the other hand, Hazard analysis and critical control point (HACCP) systems should be implemented increasingly by private industry for seafood. These must be rigidly enforced throughout the processing line and require the full understanding and cooperation of plant management and every employee. Investment in new technologies and equipment will also improve the seafood safety.

\section{CONCLUSION}

The findings of this study show that the mud crabs sold in Dhaka are highly contaminated and potentially hazardous if consumed directly or without proper cooking. But the frozen samples sold in super markets are much safer. The high bacterial load of those products may be due to inadequate farming process in addition to poor hygiene practices and sanitary conditions prevailing in the markets or the environment from which they are caught.

The presence of Vibrio spp., Salmonella spp., Shigella spp. and Staphylococcus spp. in the sampled crabs indicate the probability of outbreak of food borne diseases through consumption of infected crabs. So long term monitoring and hygienic practices are necessary to avoid such situations.

Acknowledgement: The authors are thankful to the Ministry of Science and Technology for National Science and Technology Fellowship, 2013 to Farhana Karim.

\section{LITERATURE CITED}

AHMED, K. 1992. Report of the seminar on the Mud Crab Culture and Trade. Surat Thani, Thailand, November 1991, Bay of Bengal Programme, BOBOP/REP/51, Madras, India, 1992. pp. 95-102.

APHA. 1998. Standard methods for the examination of water and waste water (20th Ed). American Public Health AssociationInc., Washington D. C. Part 9000-9221. p. 4859.

BEPB (Bangladesh Export Promotion Bureau). 2009-10. Annual Report of the Export promotion Bureau, Dhaka, Bangladesh.

BUCHANAN, B.L. 1991. Microbiological criteria for cooked ready to eat Shrimps and Crab meat. Journal of Food Technology. 4:157-165.

EDEMA, M.O., OSHO, A.T., and DIALA, C.I., 2008. Evaluation of microbial hazards associated with the processing of suya (a grilled meat product. Scientific Research and Essa.3(12): 621-626.

EEC (European Economic Community). 1992. Opinion of the Scientific Committee on Veterinary Measures Relating to Public Health on Vibrio vulnificus and Vibrio parahaemolyticus (in raw and undercooked seafood), adopted on 19-20 September 2001. 
EMIKPE, B. O., ADEBISI, T. and ADEDEJI, O. B. 2011. Bacteria load on the skin and stomach of Clarias gariepinus and Oreochromis niloticus from Ibadan, South West Nigeria: Public health implications. J. Microbiol. Biotech. Res. 1(1): 52-59.

ICMSF (International Commission on Microbiological Specifications for Foods) 1998. Microorganisms in Foods, Microbial Ecology of Food Commodities. Baltimore: Blackie Academic \& Professional.

LALITHA, K. V. and THAMPURAN, N. 2012.Bacterial flora of farmed mud crab, Scylla serrata (Forskal, 1775) and farm environments in Kerala, India.Indian J. Fish. 59(2): 153-160.

MENSAH, P., YEBOAH-MANU, D., OWUSU-DARKO,K. and ABLORDAY, A. 2002. Street food inAccra, Ghana: how safe are they? Bulletin of the World Health Organisation. 80: Nos 7.

NESTER, E.W., ANDERSON, D.G., ROBERTS, C.E. and NESTER, M.T. 2007.Microbiology : A Human Perspective (5th Ed). McCgraw Hill Publishers, New York, p. 627.

NILlA, S. S., MUSTAFA, M. G., AHSAN, D. A., KHAN, M. M. R. and KHAN, M. A. R. 2012. Bacterial Abundance In Indian White Shrimp, Penaeus indicus Collected from two Different Market Conditions of Dhaka City. Dhaka University Journal of Biological Sciences. 21(1): 29-38.

REINHARD, R. G., MC ADAMS, T. J., FLICK, G. J., WITTMAN, R. F., FRANZ, C. M.,HOLZAPFEL, W. H. and STILES, M. E. 1999. Enterococci at the cross roads of food safety.Int. J. Food Microbiol.47: 1-2.

(Manuscript received on 19 April, 2015l; revised on 13May 2015) 